\title{
An Analysis of Factors influencing the Sustainability of Private University's Music Faculty of Thailand
}

\author{
Pannawit Sanitnarathorn ${ }^{1}$, Navaya Shinasharkey ${ }^{1}$, Kittisak Poolsawat ${ }^{1}$ and Jessada Chitrakorn ${ }^{1}$ \\ ${ }^{1}$ School of Music, Assumption University of Thailand
}

\begin{abstract}
As indicated by the present aging population and fewer children situation, the number of Thai youngsters has been radically diminishing contrasted with the earlier decades and this prompts the insufficient number of students enlisting in the university level. It has influenced both public and private university however the second one has gotten a higher effect as Thai parents and children have a typical social esteem that graduating from the public university will get more pride and respect to the family. Programmes in music have been popular in the recent year; however, for the private universities offering a degree in music is attempting to survive. The researchers would like to study and research on how innovation, management strategies and organisational performance influence the private university's music programme's sustainability. Questionnaires will be collected from a proposed sample of 220 Thai private university's administrative faculties. Partial Least Square (PLS-Graph) software will be used to analyse the data and applied with Structural Equation Modeling (SEM).
\end{abstract}

Keywords: innovation, management strategies, organisational performance, organisational sustainability

\section{Introduction}

According to National Economic and Social Development Board of Thailand, in 1980 the number of school age children $(<21$ years) represented 62.3 percent of the population but by 2040, this number will drop to 20 percent of the population. The reasons are varied and complex but the reality is many Thai universities are entering a period of where change and flexibility are becoming a matter of institutional sustainability. According to education officials, in 2015's admissions period, Thai universities had up to 156,216 spots open for prospective students. However, only 105,046 applied to take the entrance exams, leaving more than 50,000 places empty [1]. If the trend continues, academics fear that some universities may be forced to close their doors.

According to the Office of the Prime Minister, Thai fertility rates plunged from 6.3 from 1964-1965 to approximately 1.82 from 2000 - 2005, which is considered lower than the replacement level and it continued to decline to 1.62 in the $2005-2010$ period [2]. The resultant change to Thailand's demographic structure has thus become a threat to sustainable economic and social development (and universities) with the aged population rapidly increasing, whereas the working-age population and school-aged children have been declining rapidly [3].

As noted above, in 2015 there was less number of students wishing to enter a university program as compared to the available seats. The future appears also bleak as student enrollment in primary and secondary schools also had 800,000 empty seats throughout the country [4]. Of the 170 Thai universities, the Rajabhat University system is the mostly likely candidate to face the crunch due to a trend shift in the majors chosen by students, with changes in the labour market having a large impact on non-scientific programs.

Further supporting data for the coming crisis in social science enrollment was seen in the 2015 as the number of participants who entered the national entrance exam dropped to 91,813 students with total availability 
at 151,000 seats [5]. The knock-on effect will eventually be a decrease in graduate students and $\mathrm{PhD}$ candidates that are available for academic and research positions. This is already being played out in 2016 by the government's decision to spend 34.3 billion baht to produce 12,290 post-doctoral researchers to meet the development of 10 targeted industries (not the social sciences) and the concept of "Thailand 4.0", which focuses on technological development and innovation [6]. In the 2016 plan, of the 1.07 billion baht earmarked for 300 scholarships, 60 scholarships are slated for ASEAN and six other countries.

According to statistics from the website of International Association of University Presidents of Thailand, among the top 100 university programs in 2015 , music was not listed. The academic pursuit of music is always considered an optional choice by university students with most viewing music as a risky profession in terms of employment and income potential as compared to professions in medicine, engineering, or business.

Enrolments in Thai university music programs continue to drop and with the subsequent competition in both public and private institutions ever increasing, the standard of quality of students that become enrolled often times becomes suspect and can with time lead to lower standards and/or disqualified students. There also appears to be a relationship between whether a student pursues a music degree from either a public or private institution and how this is viewed by families and society [7].

The bottom line is the competition for music students in fierce as enrolments have plummeted due to population demographics, more competitive foreign programs, and online courses which are often significantly lower campus attended tuition rates. Many Thai universities are struggling, particularly private ones, with financial concerns becoming first and foremast the greatest concern of university and program administrators. The ratio between lecturers and students is not in balance and especially, private universities which mainly rely on tuition fees of students. Therefore, some weak programs will need to be shut down in order to stabilise the organisational structure. It is a time to prepare for change in higher education. Things need to be done now to change the business of education before the corridors are empty and the music has stopped.

The researchers determined to use a structural equation model (SEM) to develop and understand the music faculties in private universities and the variables affecting its sustainability within 74 registered private institutions nationwide. This research will focus on factors that affect private university's sustainability. There are dramatic changes affected by the decreasing number of population and social value. Survival and to sustain in such a situation in the present circumstance is complicated and difficult and it leads to the main objective of this research.

\section{Literature Review}

\subsection{Innovation}

Innovation is characterized as adding something new to a current item or procedure. Drucker contended that innovation is the instrument of business entrepreneurship [8]. Furthermore, both innovation and entrepreneurship demand imagination and creativity. No business visionary or endeavour, however effective and enormous, can keep on holding a position of leadership unless it perceives that modern business works in a world of galloping change which makes new issues, danger and open doors and for which they need to assemble the undertaking's assets before changes have their effect felt [9].

Freeman and Soete expounded on innovation impacts on financial matters and expressed that innovation is a vital state of monetary advancement and a basic component in the focused battles of ventures and countries [10]. Innovation is a basic for the individuals who wish to accelerate or support the rate of economic development in their own particular and different countries and is basic for the long term protection of assets and change of nature. The research is done by just a modest bunch of players and they firmly control R\&D data, smothering the capacity and inspiration of outside new companies to enter the field. Still, innovation rises underneath the surface, driven by the requirement for procedure disruption [10]. 
It is related to Lemon and Sahota that states pretty much as innovate or die is one of the lessons of today's business, knowledge is progressively perceived as the key supporting asset and that organisational learning has a critical impact in guaranteeing that knowledge repositories are constantly renewed and redesigned to empower proficient responses to changes in its competitive surroundings [11].

\subsection{Management Strategies}

The management strategy alludes to the instruments that organisations use to judge the competition in the business sector compared to its rivals [12] which is the competitive strategy, management strategy, or corporate system, is the fabric of verbal and non - verbal communications in business setting the behavioural standards for the business long - term orientation [13]. In that capacity procedure ought to influence day by day activities however only or mostly those related to the organisations' expectations of its main activities on a more distant horizon [14] and expressed that a country's competitiveness relies on upon the limit of its industry to innovate and update.

In Porter's book on Competitive Strategy the concept of generic strategies cost leadership, differentiation, and focus - was presented which spoke to the option tactical positions in the industry [15]. This is reliable with Tanwar which examined 'generic strategies' expressed that essentially, strategy is around two things: choosing where you need your business to go, and choosing how to arrive to the point [16]. It was demonstrated that generic strategies incorporate 'overall cost leadership', 'differentiation', and 'focus' yet if the organisations attempt to keep up cost leadership and make a difference in the meantime, they may neglect to accomplish either [16]. They stated that organisations need to shape strategic thought and be adaptable so organisations can rapidly react to difficulties of nearby contenders. As indicated by the study's research, it was resolved that there were 3 key manifest variants or observable variables related to management strategies.

\subsection{Organisational Performance}

De Waal focused on the distinguishing variables that decide the consistent achievement of a high performance organisation and according to a broad review of the study which included non-financial performance, better financial performance, and sustained growth compared to long-term orientation and over five year's better results [17]. Kaplan and Norton changed traditional concept of organisational performance measurements with the balanced scorecard [18].

The balanced scorecard indicates that if organisations wish to increase their successful performance they must adhere to the three main ideas of sustainable development which includes economic, environmental and social. Also, according to Figge et al., sustainability management need not be concerned with economic crises if they are economically solid [19].

\subsection{Organisational Sustainability}

Organisational sustainability has been contended to be an essential objective or goal every firm must set. It was expressed to be almost the top of the management plan and it reflects strategic planning and financial results of the organisation [20].

Bertels et al. reported that a UN study of global CEOs indicated that 93 percent viewed survival as crucial for their firm's success and furthermore indicated from their own report that the key importance to corporate sustainability was organisational culture [21]. Epstein added that enterprise sustainability depends on the daily effect that a firm has on society, the surrounding environment and the financial impact of the local community [22]. 


\subsection{Proposed Conceptual Model}

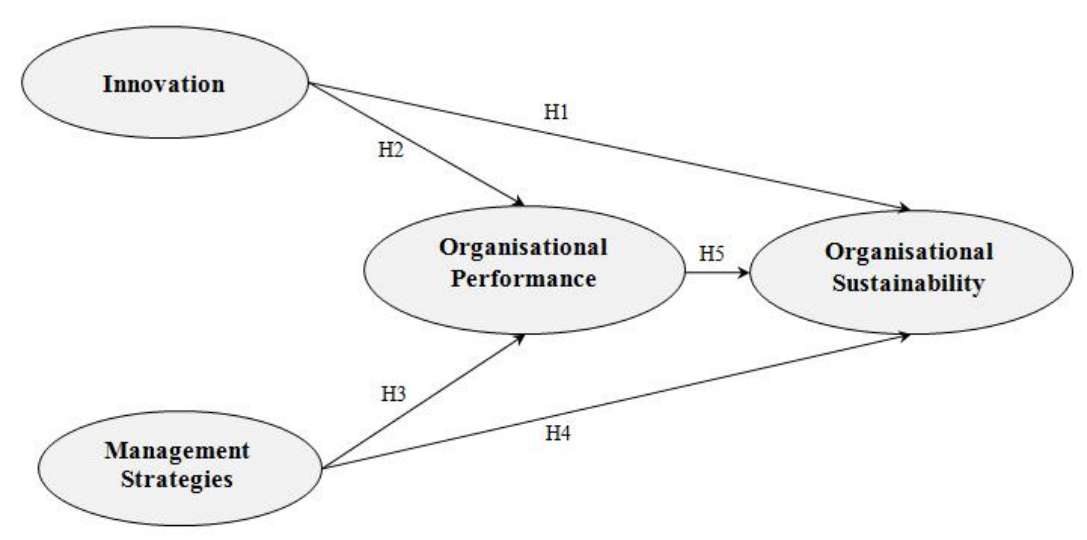

Fig. 1: Conceptual Model

\subsection{Proposed Hypotheses Model}

H1: Innovation will positively influence Organisational Sustainability.

H2: Innovation will positively influence Organisational Performance.

H3: Management Strategies will positively influence Organisational Performance.

H4: Management Strategies will positively influence Organisational Sustainability.

H5: Organisational Performance will positively influence Organisational Sustainability.

\section{Methodology}

The research focuses on the factors affecting the sustainability of private university's music faculty in Thailand. The population in this study is administrative members within the total 74 private universities and colleges in Thailand which have been registered and licensed by the Office of the Higher Education Commission of Thailand. The research will be collected by a questionnaire from 220 samples using a 5-Point Likert Scale [23]. The Structural Equation Modelling (SEM) will be conducted to test the relationships among variables of the hypothesised model [24]. The Confirmatory Factor Analysis (CFA) and reliability analysis will be conducted to measure Cronbach's alphas to ensure internal consistency. Measures were developed based on Cronbach's alpha $>0.68$. This study will then calculate Cronbach's alphas for each construct. If the value is below 0.50 , the research question will be cut off [25].

\section{Data Collection}

The data of factors affecting the sustainability of private university's music faculty in Thailand will be collected. The study will be used the Partial least squares (PLS) method and tested with PLS-Graph software to analyse the model structure. The analysis will be conducted by descriptive statistics by characterising the frequency, percentage, mean and standard deviation and will be conducted using the structural equation modelling (SEM) to determine the relationship of the factors influencing the sustainability of private university's music faculty in Thailand.

\section{Conclusion}

It has been established that the university sustainability occurs because of the innovation within the organisation that make a differentiation. Furthermore, due to management strategies factors which influence the competitive advantages from others, the organisational sustainability is created. According to the literature review, these two factors are expected to have a direct and positive impact on the sustainability of private 
university's music faculty in Thailand. It should also influence the organisational performance that influences the stabilisation of the firm to make the organisation survives.

\section{References}

[1] D. Mala. Unis face crisis as students turn away. Bangkok Post, June 2016. Retrieved from http://tinyurl.com/z3hdogx

[2] Office of the Prime Minister. Population plan during the eleventh national economic and social development plan (2012-2016). The Office of the National Economic and Social Development Board of Thailand, October 2012, pp.1011. Retrieved from http://tinyurl.com/hn4cr35

[3] T. Searchinger, C. Hanson, R. Waite, B. Lipinski, G. Leeson, and S. Harper. Achieving Replacement Level FertilityCreating a Sustainable Food Future, Installment Three. World Resources Institute, August 2013. Retrieved from http://tinyurl.com/h7jrjp9

[4] A. Sakworawit. Will Thai Universities be Able to Survive?. Manager Online, May 2016. Retrieved from http://tinyurl.com/z9xk822

[5] T. Numman. Full of Universities but an Empty Classroom: A Thai Higher Education Crisis. Post Today, April 2016. Retrieved from http://tinyurl.com/zqvjyxs

[6] Bangkok Post. Govt designs 20-year plan to churn out more researchers. Bangkok Post, August 2016. Retrieved from http://tinyurl.com/gkuqeuj

[7] K. Chareonwongsak. When a birth rate drops, how can Thai universities survive?. OK Nation, October 2016. Retrieved from http://tinyurl.com/z83cnk7

[8] P. Drucker. Innovation and Entrepreneurship, London: Pan Books Ltd.G. Hamel. The Why, What, and How of Management Innovation, Harvard Business Review. February, 1985. Retrieved from http://tinyurl.com/j81do5j

[9] O. Okpara. (September 2007). The value of creativity and innovation in entrepreneurship, Journal of Asia Entrepreneurship and Sustainability. $(3,2)$. Retrieved from http://tinyurl.com/zega9a8

[10] C. Freeman and L. Soete. The Economics of Industrial Innovation, 3rd edition. Cambridge MA: MIT, August 1997. Press. ISBN: 9780262561136. Retrieved from http://tinyurl.com/j99aj5e

[11] M. Lemon and P. Sahota. (June 2004). Organizational culture as a knowledge repository for increased innovative capacity. Technovation 24(6), 483-498. Retrieved from http://tinyurl.com/goxej48

https://doi.org/10.1016/S0166-4972(02)00102-5

[12] S. Meskendahl. (December 2010). The influence of business strategy on project portfolio management and Its success - a conceptual framework. International Journal of Project Management. 28(8), 807-817.

https://doi.org/10.1016/j.ijproman.2010.06.007

[13] G. Johnson, R. Whittington, K. Scholes, and S. Pyle. Exploring strategy: text \& cases. Harlow: Financial Times Prentice Hall. December 2010.

[14] M. Porter. What is strategy?. Harvard Business Review, November-December. 1996. Retrieved from http://tinyurl.com/oaarmj6

[15] M. Porter. The Competitive Advantage: Creating and Sustaining Superior Performance. NY: Free Press. 1985.

[16] R. Tanwar. Porter's Generic Competitive Strategies, Journal of Business and Management, 15, 1. November, 2013. 11-17. Retrieved from http://tinyurl.com/jdnj6ne https://doi.org/10.9790/487x-1511117

[17] A. A. De Waal. (April 2007). The Secret of High Performance Organizations, Management Online Review, ISSN 1996-3300. Retrieved from http://tinyurl.com/jufx5tj

[18] R. S. Kaplan, and D. P. Norton. (August 1992). Using the Balanced Scorecard as a Strategic Management System, Harvard Business Review, July-August. Retrieved from http://tinyurl.com/ozdnzdy 
[19] F. Figge, T. Hahn, S. Schaltegger, M. Wagner. (September 2002). The Sustainability Balanced Scorecard-Linking Sustainability Management to Business Strategy, Business Strategy and the Environment, Vol 11, pp. 269 - 284. Retrieved from http://tinyurl.com/z5byw73

https://doi.org/10.1002/bse.339

[20] W. J. Rothwell. Effective Succession Planning: Ensuring Leadership Continuity and Building Talent from Within - 4th Edition. New York: American Management Association, 2010. Retrieved from http://tinyurl.com/zukgdum

[21] S. Bertels, L. Papania, and D. Papania. Embedding sustainability in organizational culture. Network for Business Sustainabilit, 2010. Retrieved from http://tinyurl.com/l6nswwq

[22] M. J. Epstein. Making Sustainability Work: Best Practices in Managing and Measuring Corporate Social, Environmental, and Economic Impact, Berrett - Koehler Publishers, 2014. Retrieved from http://tinyurl.com/zkzomdq

[23] R. Likert. A Technique for the Measurement of Attitudes, In: Attitude Assessment, Summers, G.F. (Ed.). Chicago, IL., USA.: Rand-McNally and Company, 1970, pp. 149-158.

[24] R. E. Schumacker, and R. G. Lomax. A Beginners Guide to Structural Equation Modeling, Third Edition. New York: Routledge, 2010. Retrieved from http://tinyurl.com/z2sdwtr

[25] L. J. Cronbach. Coefficient alpha and the internal structure of tests. Psychometrika, 1951, 16(3), pp. 297-334. https://doi.org/10.1007/BF02310555 